\title{
THE ROLE OF THE ARMY OF THE REPUBLIC OF MACEDONIA IN DEALING WITH REFUGEE CRISIS
}

\author{
Zhanet Ristoska, PhD \\ Ministry of Defense of the Republic of Macedonia \\ E-mail: zanet.ristoska@yahoo.com \\ Biljana Popovska, PhD Candidate \\ Unviersity of Bucharest, Berlin Campus, \\ E-mail: bpopovska@yahoo.com
}

\begin{abstract}
So far Republic of Macedonia has faced large refugee crisis caused by the huge number of migrants and refugees fleding from conflict areas and trying to get to Western Europe. In the course of the second half of 2015 the situation on the southern border of the Republic of Macedonia was alarming. During August, more than 14 thousand refugees were present in the territory of the Republic of Macedonia on daily bases. This huge influx demanded an appropriate response by institutions to provide the safest way which would enable the flow of these people on the northern border and outside the Republic of Macedonia. Seen from a historical perspective this was not the first time the country had such a situation at the borders. However and from the past experience from the Kosovo crisis in 1999, this time, the country managed relatively well and quickly to activate the mechanisms to deal with such situations. The legislation of the Republic of Macedonia involves the possibility to activate Army units during a declared crisis situation to support police forces and state institutions primarily responsible for the implementation of measures and activities for such humanitarian and security threat. The subject of analysis in this paper will be legal provisions for the activation of Army units in crisis situations and specific activities and challenges Macedonian Army faced during the second half of 2015 and 2016 in relation to the refugee crisis. The recommendations in this paper are aimed at re-evaluation and completion of certain legal possibilities for the competences of institutions in dealing with crisis situations and appropriate use of units of the Army of Republic of Macedonia.
\end{abstract}


Keywords: refugee crisis, army units, security threats, institutions, activities

\section{Introduction}

EU and South Eastern Europe have faced many challenges arising from the escalating refugee crisis and the influx of large numbers of refugees from the crisis regions of the Middle East and Africa. En route towards Western Europe refugees were passing through a number of Southeast Europe countries. Macedonia was one of the main transit countries of the Balkan route through which several hundred refugees were passing on daily bases. Threats and risks from the great refugee crisis were numerous and included the likelihood of humanitarian disasters, spreading diseases and epidemics, excessive load and collapse of the economic systems of the transit countries up to direct security challenges in terms of maintaining order, preventing possible violence and guaranteeing the physical safety of refugees but also the residents of the transit or possible new resident countries for the refugees. Great was the possibility that some of these people, using the guise of refugees from conflict to penetrate the EU and South Eastern Europe coutries in order to carry out terrorist attacks and to endanger the safety of citizens and the vital values of the Member States and South East Europe.

Macedonia was part of the Balkan route through which huge number of refugees and migrants from conflict areas in Syria, Afghanistan, Iraq and some countries of Africa transited. In the course of the 2015 , about one million refugees and migrants transited the territory of the Republic of Macedonia. After the declaration of a crisis situation on the part of the territory of the Republic of Macedonia, the Army of the Republic of Macedonia (further in the text: ARM) was included and was given a legally regulated mission to deal with the challenges arising as a result of the large refugee and the migrant crisis as a support to the police forces. The Citizens of many cities in the country almost did not feel that great movement which was primarily due to the efficient involvement of the police and the army units which enabled the bulk of these refugees regularly to be recorded and to transit the territory of our country's northern border with Republic of Serbia, thus preventing a large number of refugees illegally to cross our border with Greece. Hence, R. Macedonia has served as an example for other countries on how to deal with the influx of migrants and refugees from conflict areas. With some of its units (military police and engineering units) ARM was constantly present in the field which certainly had implications related to the money spent as well as the excessive volume of daily engagement of its forces beyond the normal duties and tasks. Still, all activities undertaken by Army members in dealing with the refugee crisis had to be performed only 
in support of the police units i.e. they had no legitimacy to act independently (without police authorization), which had implications for the safety of its members and their efficiency in the execution of tasks. Unfortunately, there had been a number of injured security personnel on duty. Today, the situation at the state borders of the Republic of Macedonia is secure. The Balkan route is closed and the number of illegal crossings has been reduced drastically.

\section{Republic of Macedonia and the refugee crisis}

Macedonia wholeheartedly supported the policies of Brussels in respect of the measures and actions to deal with the refugee crisis at its national borders. It allowed humanitarian organizations without problems to provide the necessary support and assistance to migrants and refugees. However, during 2015, the number of refugees and migrants has rapidly begun to increase. Moreover, at one point in the course of August 2015 , the situation at the southern border was such that during one night 14,000 refugees and migrants were present at the railway station in Gevgelija. Overnight, the town of Gevgelija of 15,600 inhabitants has grown for more than 14,000 refugees and migrants. This situation was alarming and it was evident that only with border police the border could not be safe. Hence, the situation could have escalated and cause security implications for the country. Numerous anomalies became obvious while recording and registering the migrants. For instance, most of the refugees and migrants were men aged between 18 and 30 years. Also, some of the migrants coming from Greece had burns and wounds on their right hands. Dozens of people had the same identity documents. In addition, majority of the Frontex documents stated that those people were born on January 1 and May 5 (Ivanov Cj., 2016). Then, Macedonia was one of the few sovereign states in Europe, which alone made a decision and implemented it. Earlier, on July 19, 2015 the President of the Republic of Macedonia as its supreme Commander initiated the possibility of engaging the Army of Republic of Macedonia. During this period tactical measures were implemented to assess the deployment of the army to protect the border in a support of the police forces. The President convened the Security Council of the Republic of Macedonia and conclusions were adopted to protect the national security from the threats Republic of Macedonia was facing due to the refugees and migrants influx on the southern border. The public was informed about some of these measures and activities. Some of them were classified and were to be implemented in institutions for the purpose of prevention and management. Government took the initiative to procure the necessary equipment and some time was given to make all the preparations to put the protective fence when appropriate (Ivanov Dj, 2016). 
On 19 August 2015, the Government of Republic of Macedonia adopted a decision declaring the crisis situation in the southern and northern borders. The very next day, on August 20, decision was made to deploy ARM in support to the Ministry of Interior to deal with the declared crisis conditions due to the migrant crisis.

Initiated by the Macedonian Government and the countries along the Balkan route, an expanded ensemble of the European Commission and the Member States en route of refugees and migrants transit convened in October 2015. According to the plan of the European Union, 55,000 refugees and migrants were to remain on the Balkan territory. Macedonian President Dr. Gjorge Ivanov resolutely countered this possibility, pointing out that Macedonia had capacity for only 2,000 people in the temporary transit centers, of which 1000 at the entry and 1000 at the exit. He also recalled Republic of Macedonia experience of 1999 when the country was enforced to accept 360,000 refugees from Kosovo at the state expense (http://president.mk/mk/2011-06-17-09-5507/2011-07-19-10-40-39/3488.html).

On 15 November, President of the Republic of Macedonia convened the Security Council of the Republic again and opted for concrete measures and activities to actively involve military units in support to the police units in regulating the situation on the southern border with Greece. "Greece has not shown interest in cooperating with us, except at the level of the police officers engaged at the border. To my personally request to the Greek Prime Minister Tsipras, the refugees and migrants from the illegal camp Idomeni were displaced from the Macedonian border. Greece displaced them to other locations, which contributed to opening new alternative Balkan routes. This has been passed to the Bulgarian prime minister and president who expressed gratefulness as we have pointed out that they should expect the new wave to come through their territory.

On 2 March 2016, European Council President Donald Tusk came to Macedonia. A plan to regulate the migrant wave was presented to him. It involved a regulation with one entry and one exit point. Macedonia's position was that the so called "Principle of the tube" should be implemented on the entire Balkan route so it could be regulated. Brussels followed in this regard. Idomeni became entry point at the border stone 59 while the exit point was at the Austrian-German border. So,ehen the route was established, a"valve could have been installed" to close the Balkan corridor.

After the Macedonian route was close an attempt was made for moves to Italy via Albania. However, it dried up due to the snow in Albania. There was also a second route through Bulgaria. But, Bulgaria and Greece erected a fence at the common border with Turkey. Later, an attempt was made for movements via sea or more specifically from Turkey through Bulgaria and Romania as entry to Europe. However, due to the unfavorable weather conditions and large ocean waves, the migrants abandoned the route. 
On March 11, 2016, in an interview for the biggest-selling German newspaper "Bild", President of the Republic of Macedonia Dr. Gjorge Ivanov pointed out that Macedonia was put into an absurd situation as non NATO and EU member to guard Europe from the European Union.

So, although, Macedonia was one of the most affected countries by the huge influx of refugees and migrants among the conflicts' impacted countries it managed successfully without compromising the security situation in the country. It responded appropriately and effectively to this major challenge by utilizing all legal possibilities, human and material resources and effective strategies and tactics to deal with it.

\section{Some aspects of the legislation regarding the use of the Army of Republic of Macedonia}

ARM is the armed force of all citizens of the Republic. It is composed of permanent and reserve forces. Organization of the units, commands, staffs and institutions, as well as their size, structure, number, composition and mission are laid down in the organization and formation of the Army. The army consists of branches, types and services. Manning of the army is carried by the organizational structure and formation of the Army. Manning in the armed forces is done by professional soldiers, military officers and civilians serving in the Army, as well as resources. Manning of the reserve forces is done with reserve conscripts. Management of the armed forces in carrying out the tasks is laid down in the Constitution and is under the jurisdiction of the President as Commander in Chief of the Armed Forces. According to the Defense Law, commanding role of the Army is performed on the principle of one leader, subordination and unity in commanding to engage forces and means. According to the latest lineup, the Army is organized in three levels as strategic, operational and tactical one. Command and control of the ARM units at strategic level is carried out by the President of the Republic of Macedonia as a supreme commander of the army. President of the Republic carries out the Commanding role with the Army, through the Minister of Defense and in accordance with the Constitution. Chief of Staff and the commanders directly command with the Army units and facilities in accordance with the regulations for commanding adopted by the President of the Republic.

The role of the army in one sovereign and independent state must be legally supported and determined. In Republic of Macedonia since its independence until today a number of laws and regulations, as well as political and strategic documents governing the use of military units were adopted. Immediately after the independence, the Parliament passed the Constitution of RM (1991). Constitution as the highest normative legal act regulates several areas pertaining to the Republic of Macedonia 
as a sovereign, independent, democratic and social state. Constitutional solutions have created a basic framework to build the defense of the Republic of Macedonia. Defense system, as a subsystem of the system of national security is intended to protect the freedom, independence, sovereignty and territorial integrity of the Republic of Macedonia from all forms of military threats and other forms of use of military force. The defense of the Republic of Macedonia is discussed in more details in Chapter 7 of the Constitution which is titled "Defense of the Republic of war and emergency situation." It regulates the military and the state of emergency, the manner of declaration, the duration of emergency and martial law and the powers and responsibilities of the bodies during that state. Article 122 states that: "The armed forces of the Republic of Macedonia protect the territorial integrity and independence of the Republic. The defense of the Republic is regulated by a law adopted by a two-thirds majority of the total number of MPs. (Macedonian Constitution,1991)

The first Law on Defense of the Republic of Macedonia was adopted in 1992, and it was later repeatedly amended so that further defines all matters relating to the defense of the country. In 2001, a new Law on Defense was adopted (Defense Law,2001). According to the Defense Law of 2001, "the defense of the republic is exercised by the citizens, the state government and the armed forces as the Army of Republic of Macedonia". Defense Law of 2001 over the past decade repeatedly changed and was amended. The Defense Law precisely and expressly defines the role of the army and its units within the country and the participation of the army in activities outside the territory of the State. Chapter IV of the Defense Law - Army of Republic of Macedonia, specifies how ARM is organized and why it is organized: "The army is organized, prepared and trained to conduct armed struggles and combat actions to exercise its constitutional role (Defense Law,2001)." The Law on Defense sets forth the organization and composition of the Army by types, branches and services. Tasks and duties of the General Staff in the system of Defense, as well as issues concerning the responsibilities about commanding the army, manning, mobilization, preparation, financial security, chains of command and control, crypto protection and counter electronic security are also defined. Article 40 - Participation of the Army in emergency relief activities, explains the principle of involvement of army units in case of emergency. The provisions of the Act further defined in the Strategic Defense Review (further on: SDR) of (2003). President acts in the framework of the Constitution and the Law. Functions of the President in the defense area are set forth in Article 18 of the Defense Law of 2001. These activites constitute the office of the supreme command as the highest level of command in the armed forces of the Republic of Macedonia. The provision of Article 18, paragraph 1, item 5 of the defense prescribes the authority of the president to "adopt documents to engage the Army and order it." Based on this provision, 
none other than the President of the Republic may issue an order to engage the Army. A similar conclusion applies to the provision of section 8 of the defense law that provides the authority of the president to "order mobilization of the Army." From the wording of this provision, it may be concluded that no one else, and in no case cannot order mobilization of the Army or part thereof other than the President of the Republic. Basic constitutional duties of the president are to represent the country in a role of a head of the state and carry out the supreme commanding with the armed forces in a capacity of a commander in chief(Macedonian Constitution,1991).

In 1998, the first Defense Strategy of the Republic of Macedonia was adopted as a basic document presenting the fundamental national values and interests and identifying threats and risks to national security. In 2001 it became evident that the political framework of the Strategy of 1998 should not be exceeded and it does not correspond to the specific events and conditions of the security plan. So, until then the Army of Republic of Macedonia developed as a force for conventional actions. However, after the events of 2001, it became clear that due to the developments and security analysis ion national and global level, it inevitably had to be restructured in order to respond to the increased asymmetrical threats.

In 2003, Concept for National Security and Defense was developed and adopted by the Parliament. It established platform based on which all the goals, attitudes, activities and measures undertaken by the Republic of Macedonia to become a country with a higher degree of national security and the closer to the countries which are part of the collective security systems to build upon. The Concept for National Security and Defense of the Republic of Macedonia is the most important document which provides the basis for improving the specific laws and documents. Then, based on conceptually founded views on vital security issues the implementation of standards and operating procedures closer to NATO standards began. In the course of 2003, the first phase of the Strategic Defense Review was made based on the conceptual commitments laid out in the Concept of National Security and Defense policy framework i.e., SOP. Later, activities proceeded with adoption of standards and commitments to the development of the Army and accession to NATO, thus completing the second and third phase. The first phase is a part when documents that served as basis, guidelines and planning assumptions were prepared. The second phase covered the part on assessment of the forces.

Primary missions of the defense of the Republic of Macedonia are defined in the second phase of the Strategic Defense Review. They are: the defense of the country; operations in support of peace; contribution in dealing with regional conflicts; protecting the broader interests of the country. 
Further below the tasks of the mission "defence of the country", are discussed. They are:

1.1. defense and protection of the territorial integrity and independence of the Republic of Macedonia in accordance with the Constitution, the Law on Defense and the National Concept for Security and Defense of the Republic of Macedonia;

1.2. support to the forces of the Interior Ministry (further on: MOI) in dealing with the threats, risks and safety hazards, which exceed their capabilities and capacities;

1.3. support of the state authorities, local government units and other government and non-governmental organizations and institutions, as well as citizens in dealing with natural disasters and epidemics, technological and other institutions and other incidents;

1.4. performing operations and military support as host country of the international forces in the territory of the Republic of Macedonia to perform tasks and responsibilities taken by Republic of Macedonia including joint defense of the territorial integrity and sovereignty of Macedonia.

As subtasks of the task 1.2. the following situations have been defined:

-support of MOI with intelligence;

- support MOI with resources and capabilities that exceed their capacities;

- support the MOI in border security;

- support the $\mathrm{MOI}$ in executing actions of securing facilities of importance

for the defense;

- support the $\mathrm{MOI}$ in dealing with asymmetric threats.

Later on in the text the Strategic Defense Review (further on: SDR) it is explained that according to the developments of the defense missions ARM should define the actions for its implementation. For the subtask "support units of the Interior Ministry" the SDR precisely defines the activities and the specific cases with/for which Army units will support the police.

Strategic Defense Review was made in order to specify the tasks of the armed forces in defending the country from abroad. It also took care to answer the previous dilemmas regarding the use of the armed forces in security threats which are not external aggression to our state, but relate to conditions in a disturbed security situation in the country due to other reasons and situations in which police units as primarily responsible for these situations are not able to respond independently.

Law for Crisis Management, adopted in 2005, in its provisions also covers situations of crisis requiring support from the Army troops. As far as the role of parts of the army in handling emergency and crisis situations caused by natural, technological and other sources of danger in terms of removing the effects which existed before as legal provisions (Law Defense Ordinances for civil defense, etc.). However, it is the first 
law that deals in detail with this issue and legalizes the use of military units which within the state are used to support police forces in dealing with crisis situations. Armed Forces that can be used for participation in disaster management and humanitarian emergencies are precisely defined in SOP missions. In addition, conditions under which they can be engaged are provided in Article 32 of the Law on Crisis Management. Under this law, to use military forces for crisis management in support of the police, the Steering Committee on Crisis Management will have to make a proposal through the Government to the President of the Republic. The proposal must specify the type and number of forces and capabilities of the ARM, the purpose and tasks they are required for and the duration of the activities. Coordination in deciding is performed by the police while commanding the units of the Army, participating in the operation is the responsibility of the formational commanders (Law on Crisis Management,2005).

\section{Army units in support of the police in dealing with the refugee crisis}

In the previous section we introduced the main legislative commitments for the mission, tasks and the use of the Macedonian Army, its formation, method of management and command. Development and changes of the legislation made possible for ARM units to be used in support of the forces of the Interior Ministry in dealing with the threats and risks over the security of the country.

Members of the Army units, in conjunction with the MOI in border security, were engaged to close the routes used by refugees and migrants. Also, members of the Army were engaged in tackling the rampant infiltration of refugees and migrants into the Republic of Macedonia. In addition, their pick up and transport or reporting to the Ministry of Interior was carried out. Also, during the entire time of the crisis, engineer units of the Army, which provided the appropriate engineering support in dealing with the situation at the state border were engaged. All these activities imply constant engagement of ARM in conducting patrols along the border, organizing meetings and observation posts, and continuous reconnaissance of the terrain.

The units of the Army of Republic of Macedonia were engaged round the clock as a support to the police units on the southern border. Based on the decision of the president and the order issued by the General Staff as well as and in accordance with the plans for the use and deployment of the Army, they performed tasks within the scope of assistance and support to the Ministry in dealing with the crisis. A large number of illegal crossing of the state border were prevented and persons were transported or escorted to the transit center in Gevgelija for further processing. Again, during the intensified refugee crisis Army exercised the experience gained as during the $12^{\text {th }}$ rotations in Iraq 
and $24^{\text {th }}$ rotations in Afghanistan. In only two days, the army managed to build a $20 \mathrm{~km}$ long security fence. By setting the fence, the flow of migrants was completely regulated at the entry point of the famous stone 59 .

Army and police units were properly organized in response to the crisis by declaring a crisis situation in the border area. Also, there was coordination on daily basis with the Center for Crisis Management and all ministries in the Covernment of Macedonia, UNHCR, IOM and other international and national NGOs. Humanitarian aid and reception conditions were coordinated by the Ministry of Labor and Social Policy. With the installation of the fence on the part of the state border of the Republic of Macedonia to Greece mass crossing of the border was prevented.

However, we should say that there was not enough people (police and army), for hermetically to close the southern border. It should be noted that army units are with no police authorizations and coordination and management are done by police members which certainly complicates and hinders in some respects the efficiency of handling detainees. Also, in that period problems arose in relation to inadequate capacity to accommodate persons in detention centers. Reception Center in Gevgelija has a capacity of 1,920 persons (in areas inside and outside the temporary facilities). The center can accommodate 569 people on 24-hour care. In addition to the shelters provided by various entities this figure can be increased to a maximum of 812 persons. Maximum capacity of the entry in the temporary transit center in Tabanovce is 991, while for 24-hour accommodation the capacity is 356 persons. With shelters provided by various entities present in the center, the capacity is increased to a maximum of 510 persons. It is necessary to increase the number and capacity of the officials of the border police at points of entry in order to handle the large and the complex migratory flow and for providing adequate efficient and effective identification and registration. It is necessary to improve the mechanisms to control the crowd. It is also necessary to intensify cooperation with the countries of the region and with the $\mathrm{EU}$ in order to reach and prepare a joint and unified response to the crisis. Intelligence should be share with the countries of the region and the EU in order to protect the country and for a prevention of possible terrorist attacks. It is necessary to design appropriate financial structure for crisis response which relies on government capacities, as well as to the appropriate humanitarian organizations with international and national character and the financial assistance from the EU. ${ }^{69}$

As a comparison to Macedonian case further in the text a comparison of the situation in the Republic of Slovenia, which also had a large influx of refugees and migrants at the border with Croatia is provided. Slovenia has actively been involved in addressing

${ }^{69}$ The data for most of this part of the paper are obtained by analysis and synthesis of official reports and declarations of the General Staff and the Center for crisis management during the crisis period http://morm.gov.mk/ http://www.arm.mil.mk/ http://www.cuk.gov.mk/mk/ 
migrant crisis. The country supported all the efforts to prevent illegal migration by participating in two operations in the Mediterranean, with the multipurposed patrol boat "Triglav". Certainly, the situation with the migrant routes through the Western Balkans was of a concern for Slovenia. Later developments indicate possibility of a second wave of migration. In regard to this, Slovenia is intensively preparing for it. "We continue to support EU policies related to migration. Public should understand that the so-called "Wave-through" policy is not an option. At the same time, the countries of this route should refrain from independent decisions and should continue close coordination, especially if the situation escalates". In this context, Slovenia repeatedly highlighted the need to support the Western Balkans, particularly Macedonia. We highly appreciate the responsible way in which Macedonia had to deal with the situation. Slovenian police helped the Macedonian police with a donation of equipment, as well as in controlling the border and illegal migration. At present, the ninth group of Slovenian police officers help at the Macedonian border. Migration wave in Slovenia was managed by the police on a daily basis, but also by the 376 members of the Slovenian Armed Forces and 295 members of the administration for protection and disaster relief, which operates within the defense sector as well as by volunteers subordinated to these institutions. Slovenian Armed Forces gave logistical support system for civil protection and the police, assisted in the protection of the national borders and certain buildings/facilities and areas. In addition, the Parliament of Slovenia with a two-thirds vote approved an amendment to the Defense Law which enabled the Slovenian Armed Forces to have additional powers to protect the border. In order to increase the sustainability of the Slovenian Armed Forces, they were additionally manned by contracting the reserve forces. With these ammendements and opportunities Slovenian Armed Forces have successfully addressed the needs and requirements of state institutions and have not registered any incidents so far. (From the Interview with Minister of Defense of Slovenia Andrea Katic for the Defence magazine "Shield", November 2016).

\section{Conclusion}

Currently, the Army has the right skills to fulfill the primary mission - defense and protection of the territorial integrity and independence of the Republic and to protect the life and safety of its citizens. When other state institutions (e.g., MOI / Police, the Center for Crisis Management, Protection and Rescue Directorate and others) are leading institutions in the response to an event of non-military nature, the Army always has a supportive role. To fulfill this role, the army has military capabilities to support the police and other state institutions in the protection of the critical national infrastructure, 
to support in dealing with the consequences in the event of a terrorist attack, and to support state institutions in case of natural disasters; epidemics, technological and other risks and crises.

During the past i.e., after the crisis was declared on the part of the territory of the Republic of Macedonia, Task Forces of the Army of Republic of Macedonia in more than 200 rotations were engaged. Main mission of these forces was to achieve coordination and collaboration with the forces of the Interior Ministry in closing routes for illegally border crossing, dealing with controlled and uncontrolled entrance at the territory of the country by migrants, their gathering together and transport/escort to the Ministry of Interior as well as to provide engineering support.

However, we can conclude that for greater efficiency and safety of members of the Army in meeting these legal given opportunities, it might be necessary certainly depending on the security assessment for a given crisis situation in these activities to provide additional authority and powers through amendments in the legislation.

\section{References:}

1. Бакрески Оливер и Димче Петровски (ур.) (2015), Реформи во одбраната, Скопје: Министерство за одбрана.

2. Гоцевски Т., (2000) Одбранбено осамостојување на Македонија, Куманово: Македонска ризница.

3. Котески Г., (2014) АРМ низ призмата на националната безбедност, Скопје: Јофи-скен.

4. Law on Defense of the Republic of Macedonia, "Official Gazette" no.42 / 01

5. Law on Crisis Management, Official Gazette "No. 29, 2005

6. Ministry of Defense of Republic of Macedonia, (2012) White Paper on Defense, Skopje: Ministry of Defense

7. Ministry of Defense, (2014) Long-term Defence Development Plan 2014-2023

8. Ministry of Defense, (2003) Strategic Defense Review, political framework

9. Нацев, 3. и Петровски Димче, (2009) АРМ кон НАТО, концептуален пристап и организационен развој, Скопје: Филозофски факултет

10. Николовски, И. (2003), „Армијата на Република Македонија и нејзините реформи за членство во НАТО“, во: Македонија во НАТО, Куманово: Форумпринт.

11. Ivanov. Cj. (2016) "Geostrategic and political position of the Republic of Macedonia during the migrant and refugee crisis "In Contemporary Macedonian Defence, Volume 16,N 31, Skopje,>Ministry of Defence, Skopje, 2016

12. „Штит“, магазин на Министерството за одбрана Република Македонија 